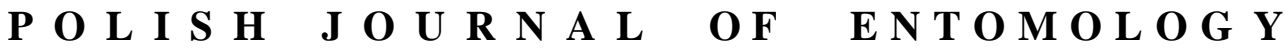

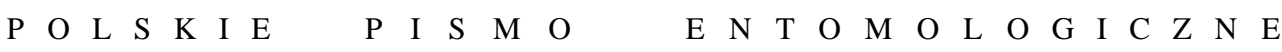

VOL. 84: 289-304

Lublin

30 December 2015

DOI: $10.1515 /$ pjen-2015-0025

\section{Symbiotic microorganisms of the leafhopper Deltocephalus pulicaris \\ (FALlén, 1806) (Insecta, Hemiptera, Cicadellidae: Deltocephalinae): molecular characterization, ultrastructure and transovarial transmission*}

\author{
Michą KobiaŁKA ${ }^{1}$, AnNA Michalik ${ }^{1}$, MARCIN WALCZAK ${ }^{2}$, \\ ŁUKASZ JUNKIERT ${ }^{2}$, TERESA SZKLARZEWICZ ${ }^{1}$
}

${ }^{1}$ Department of Developmental Biology and Morphology of Invertebrates, Institute of Zoology,

Jagiellonian University, Gronostajowa 9, 30-387 Kraków, Poland, e-mails:

michal.kobialka@uj.edu.pl,a.michalik@uj.edu.pl, teresa.szklarzewicz@uj.edu.pl ${ }^{2}$ Department of Zoology, Faculty of Biology and Environmental Protection, University of Silesia, Bankowa 9, 40-007 Katowice, Poland, e-mails: marcin.walczak@us.edu.pl, lukasz.junkiert@wp.pl

\begin{abstract}
The ovaries of the leafhopper Deltocephalus pulicaris are accompanied by large organs termed bacteriomes, which are composed of numerous polyploid cells called bacteriocytes. The cytoplasm of bacteriocytes is tightly packed with symbiotic microorganisms. Ultrastructural and molecular analyses have revealed that bacteriocytes of $D$. pulicaris contain two types of symbionts: the bacterium "Candidatus Sulcia muelleri" and the bacterium "Candidatus Nasuia deltocephalinicola". Both symbionts are transovarially transmitted from the mother to the next generation.
\end{abstract}

KEY WORDS: Hemiptera, leafhoppers, Deltocephalinae, symbiotic microorganisms, transovarial transmission of symbionts.

\footnotetext{
* The paper is dedicated to Prof. Wacław WOJCIECHOWSKI in recognition of his great contribution to the taxonomy and faunistics of Hemiptera.
} 


\section{INTRODUCTION}

Deltocephalus pulicaris (FALLÉN, 1806) is a representative of the subfamily Deltocephalinae of the family Cicadellidae (Hemiptera: Cicadomorpha). Since the majority of the Deltocephalinae leafhoppers feed on xylem sap, which is extremely poor in amino acids, they obtain substances necessary for life from their obligate symbiotic microorganisms (DOUGLAS 1998, 2003, 2006, BAUMANN 2005).

On the basis of histological observations, BUCHNER (1965) distinguished two types of symbionts: primary symbionts (also termed P-symbionts) and accessory symbionts (also termed secondary or facultative or S-symbionts). The symbiosis between insects and primary symbionts is a result of an ancient infection of an insect lineage's ancestor by a microorganism; these symbionts therefore occur in all representatives of this lineage (e.g. Buchnera aphidicola in aphids, Carsonella ruddii in psyllids) (Douglas 1998, 2006, BAUMANN 2005, 2006, MORAN \& DALE 2006). Recent molecular analyses have revealed that primary symbionts are responsible for the synthesis and supply of essential nutrients to their host insects (Douglas 2006). The primary symbionts living in the body of hemipterans may be either prokaryotic (bacteria) or eukaryotic (yeast) (BUCHNER 1965, BAUMANN 2005, 2006, KIKUCHI 2009). In most plant sap feeding hemipterans their symbionts are harboured in the cytoplasm of giant cells called bacteriocytes (if bacteria) or mycetocytes (if yeast). These microorganisms are transovarially (vertically) transmitted between generations (BUCHNER 1965). The accessory symbionts may be present intracellularly (in bacteriocytes or in other types of cells, e.g. fat body cells) or extracellularly in the haemolymph. Their occurrence in an insect body is a consequence of a more recent infection of an ancestor (review: BAUMANN 2005). For that reason these microorganisms do not occur in all representatives of insect groups: they may be found only in some populations of a species (review: BAUMANN 2005). S-symbionts are transmitted both transovarially and between members of the same population (horizontally). Recent studies have shown that these symbionts may play variable roles, e.g. they help to survive heat stress, attacks by parasitic hymenopterans or pathogenic fungi (e.g. MONTLOR et al. 2002, OLIVER et al. 2003, SCARBOROUGH et al. 2005).

Earlier histological studies by MÜLLER (1962) and BUCHNER (1965) and more recent molecular analyses (TAKIYA et al. 2006, URBAN \& CRYAN 2012, BENNETT \& MORAN 2013, ISHII et al. 2013, KogA et al. 2013, MichALIK et al. 2014a, SZKLARZEWICZ et al. 2015) have shown that Cicadomorpha and Fulgoromorpha (except Delphacidae), as a rule, harbour the obligate Bacteroidetes bacterium "Candidatus Sulcia muelleri" (hereafter Sulcia), which is accompanied by one or two bacterial species belonging to the phylum Proteobacteria. In Cicadomorpha and Fulgoromorpha all symbiotic microorganisms provide their hosts with essential amino acids (TAKIYA et al. 2006, WU et al. 2006, MCCUTCHEON 
et al. 2009, MCCUTCHEON \& MORAN 2010): TAKIYA et al. (2006) have therefore named them "coprimary symbionts".

Since recent studies have shown that the Deltocephalinae leafhoppers (SACCHI et al. 2008, IsHII et al. 2013, BENNETT \& MORAN 2013, KoBIAŁKA et al. 2015) contain diverse symbionts, the aim of this study was to characterize the symbiotic system of the common leafhopper $D$. pulicaris, i.e. the types of symbionts, their ultrastructure, distribution in the body cavity and mode of transovarial transmission.

\section{MATERIAL AND METHODS}

\section{Insects}

Adult females of $D$. pulicaris were collected from herbaceous plants in Kraków, Częstochowa and Bielsko-Biała (Poland) from June to September during 2014.

\section{Light and electron microscopy}

Dissected ovaries and bacteriomes from 20 individuals were fixed in 2.5\% glutaraldehyde in $0.1 \mathrm{M}$ phosphate buffer ( $\mathrm{pH} 7.4)$ at room temperature. The material was then rinsed in the buffer with the addition of $5.8 \%$ sucrose, postfixed in $1 \%$ osmium tetroxide (in the same buffer), dehydrated in a graded series of ethanol and acetone and embedded in the epoxy resin Epon 812 (Serva, Heidelberg, Germany). The epon blocks were cut into two kinds of sections: (1) semithin sections (thickness $1 \mu \mathrm{m}$ ) which were stained with $1 \%$ methylene blue in $1 \%$ borax and photographed under Leica DMR and Nikon Eclipse 80i light microscopes, and (2) ultrathin sections (thickness $90 \mathrm{~nm}$,) which were contrasted with lead citrate and uranyl acetate and photographed under Jeol JEM 100 SX and Jeol JEM 2100 (Jeol, Japan) electron transmission microscopes (TEM) at $80 \mathrm{kV}$.

\section{DNA isolation and PCR}

The dissected bacteriomes from 80 individuals were fixed in $100 \%$ ethanol, then washed twice in sterile water and homogenized in $120 \mu 10.7 \mathrm{M} \mathrm{NH}_{4} \mathrm{OH}$. The homogenate was incubated at $100^{\circ} \mathrm{C}$ in alkaline conditions for $20 \mathrm{~min}$. Following incubation, the sample was centrifuged (5 min, $12000 \mathrm{rpm}$ ), after which two volumes of $96 \%$ ethanol and 1/10 volume of $3 \mathrm{M}$ sodium acetate were added to the supernatant. DNA precipitations were carried out for $30 \mathrm{~min}$ at $-20^{\circ} \mathrm{C}$. After centrifugation $\left(15 \mathrm{~min}, 12000 \mathrm{rpm},+4^{\circ} \mathrm{C}\right)$, the DNA pellet was washed in $250 \mu \mathrm{l}$ of $70 \%$ ethanol and centrifuged (15 min, $12000 \mathrm{rpm}$, room temperature). Then, the DNA was dried for $15 \mathrm{~min}$ at $37^{\circ} \mathrm{C}$, dissolved in $20 \mu \mathrm{l}$ sterile water and stored at $-20^{\circ} \mathrm{C}$ for further analysis. 
The PCR was run with a total volume of $20 \mu$. The mixture included the following components: $2 \mu 1$ 10x PCR buffer, $1 \mu 125 \mathrm{mM} \mathrm{MgCl}_{2}, 0.5 \mu 110 \mathrm{mM}$ deoxynucleotide triphosphate (dNTP) mixture, $0.5 \mu \mathrm{l}$ each $10 \mathrm{mM}$ forward and reverse primers, $2 \mu 11000$ $\mathrm{ng} / \mu \mathrm{l}$ extracted DNA, $1.25 \mathrm{U}$ JumpStart $^{\mathrm{TM}}$ Taq DNA polymerase (Sigma-Aldrich, Germany) and $13 \mu \mathrm{l}$ sterile, deionized water. The $16 \mathrm{~S}$ rDNA of symbionts was amplified using specific primers: 10CFBFF (5'AGAGTTTGATCATGGCTCAGGATG3') and 1515R (5'GTACGGCTACCTTGTTACGACTTAG3') for the Sulcia symbiont (MORAN et al. 2005); 10F (5'AGTTTGATCATGGCTCAGATTG3') and 650R (5'CACCGGTACATATGAAATTCT3') for the betaproteobacterial symbiont (TAKIYA et al. 2006). The PCR reaction was performed under the following conditions: an initial denaturation step at $94^{\circ} \mathrm{C}$ for $3 \mathrm{~min}$, followed by 33 cycles at $94^{\circ} \mathrm{C}$ for $30 \mathrm{~s}, 50^{\circ} \mathrm{C}$ (for primers $10 \mathrm{~F}$ and $650 \mathrm{R}$ ) or $55^{\circ} \mathrm{C}$ (for primers $10 \mathrm{CFBFF}$ and $1515 \mathrm{R}$ ) for $40 \mathrm{~s}, 70^{\circ} \mathrm{C}$ for $1 \mathrm{~min}$ $40 \mathrm{~s}$ and a final extension step of $5 \mathrm{~min}$ at $72^{\circ} \mathrm{C}$. PCR products were subjected to sequencing in two directions.

The sequences obtained were deposited in the GenBank database with accession numbers KR904883 and KR919612.

\section{Phylogenetic analysis}

The sequences were edited and proofread in BioEdit Sequence Alignment Editor 5.0.9 (HALL 1999). The phylogenetic trees were constructed on the basis of sequences of $16 \mathrm{~S}$ rDNA of $D$. pulicaris symbionts and homologue sequences downloaded from GenBank. All sequences were aligned using ClustalX 1.8 (THOMPSON et al. 1997). Phylogenetic relationships among symbionts were estimated using Beast version 1.6.1 (RAMBAUT \& DRUMMOND 2007).

\section{RESULTS}

\section{Gross morphology of the ovary of $D$. pulicaris}

The paired ovaries of $D$. pulicaris are composed of seven telotrophic ovarioles (for further details concerning the classification and organization of insect ovarioles, see BÜNING 1994, BILIŃSKI 1998). An individual ovariole is divided into four well-defined regions: a terminal filament, tropharium (trophic chamber), vitellarium and ovariolar stalk (pedicel) (Fig. 1). The spindle-shaped tropharium contains individual trophocytes (nurse cells) and early previtellogenic oocytes (arrested oocytes). The morphological gradient of trophocytes exists along the tropharium (its apical part houses small trophocytes, whereas central and basal ones contain large cells). All trophocytes and arrested oocytes are connected with the central part of the tropharium known as a trophic core: trophocytes via 
cytoplasmic processes, oocytes via short, thin nutritive cords. The vitellarium contains several linearly arranged growing oocytes in the consecutive stages of oogenesis, i.e. previtellogenesis, vitellogenesis and choriogenesis. The vitellarial oocytes are surrounded by a monolayered follicular epithelium. During previtellogenesis RNAs and organelles are stored in the cytoplasm of the oocyte. Vitellogenic growth is characterized by an increase in oocyte volume as a result of the accumulation of reserve substances such as yolk granules and lipid droplets. During the last stage - choriogenesis - the follicular cells produce precursors of egg envelopes.

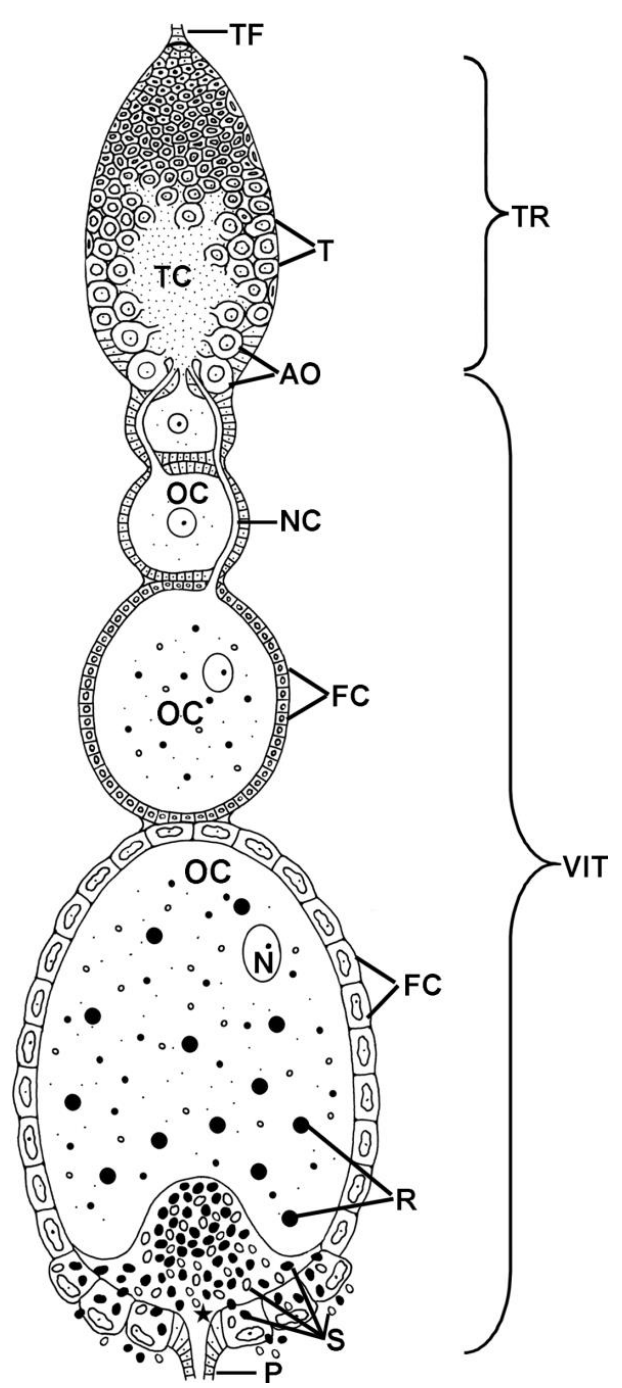

Fig. 1. Schematic representation of the ovariole organization and transovarial transmission of symbionts in $D$. pulicaris. The symbiotic bacteria (S) invade the posterior pole of the terminal oocyte. Asterisk - perivitelline space; AO - arrested oocyte; FC - follicular cells; $\mathrm{N}$ - oocyte nucleus; NC - nutritive cord; OC - oocyte; P - ovariolar stalk (pedicel); $\mathrm{R}$ - reserve substances; $\mathrm{T}$ - trophocyte; TC - trophic core; TF - terminal filament; TR - tropharium; VIT - vitellarium. 


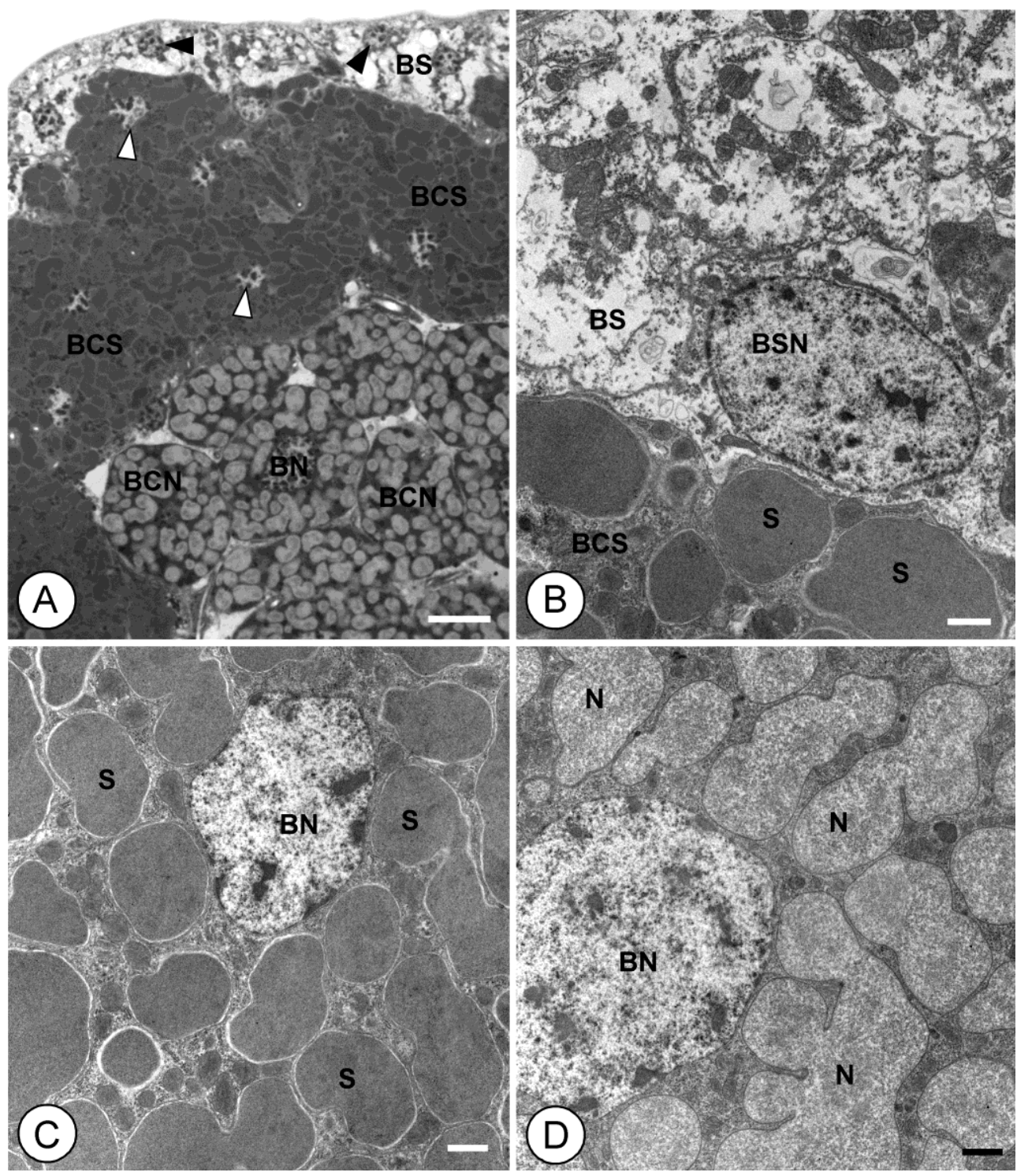

Fig. 2. Organization of the bacteriome of D. pulicaris.

A. Part of the bacteriome consisting of bacteriocytes with the bacterium Sulcia (BCS) and bacteriocytes with the bacterium Nasuia (BCN) (cross section). The bacteriome is surrounded by a monolayered sheath (BS). BN - nucleus of the bacteriocyte with bacterium Nasuia; white arrowheads - nuclei of bacteriocytes with the bacterium Sulcia; black arrowheads - nuclei of the cells of the bacteriome sheath. Methylene blue, scale bar $=20 \mu \mathrm{m}$. B. Part of the bacteriome sheath (BS) and bacteriocyte (BCS) containing the bacterium Sulcia (S). BSN - nucleus of the cell bacteriome sheath. TEM, scale bar $=2 \mu \mathrm{m}$. C. Part of the bacteriocyte filled with the bacterium Sulcia (S). $\mathrm{BN}-$ bacteriocyte nucleus. TEM, scale bar $=2 \mu \mathrm{m}$. D. Part of the bacteriocyte filled with the bacterium Nasuia $(\mathrm{N}) . \mathrm{BN}$ - bacteriocyte nucleus. TEM, scale bar $=2 \mu \mathrm{m}$. 


\section{Ultrastructure and molecular identification of symbiotic microorganisms of $D$. pulicaris}

In the body of $D$. pulicaris, in the near neighbourhood of ovaries, large organs termed bacteriomes are present (Fig. 2A). In each bacteriome two well-defined parts can be distinguished: (1) the part containing bacteriocytes with pleomorphic bacteria that stain intensely with methylene blue (Fig 2A) and are electron-dense as seen under an electron transmission microscope (Fig. 2B, C), and (2) the part containing bacteriocytes with pleomorphic bacteria that stain less intensely with methylene blue (Fig. 2A) and appear electron-translucent under an electron transmission microscope (Fig. 2D). The bacteriomes are surrounded by a single layer of epithelial cells, called the bacteriome sheath (Fig. 2A, B). Ultrastructural observations have revealed that there are no symbiotic bacteria in the bacteriome sheath (Fig. 2B).

Molecular identification of symbionts of $D$. pulicaris was performed based on the analysis of their $16 \mathrm{~S}$ rDNA sequences. PCR amplification using a specific pair of primers revealed that the symbiotic bacteria of $D$. pulicaris belong to the phylum Bacteroidetes and to the phylum Proteobacteria (class Betaproteobacteria). Blast searches of the 16S rDNA databases using $16 \mathrm{~S}$ rDNA of Bacteriodetes symbiont identified it as a bacterium "Candidatus Sulcia muelleri" with the greatest similarity to the Sulcia symbiont of the Deltocephalinae leafhopper Matsumuratettix hiroglyphicus (MATSUMURA, 1914) (tribe Deltocephalini) [JQ898313]. The 16S rDNA sequence of the betaproteobacterial symbiont most resembles that of the bacterium "Candidatus Nasuia deltocephalinicola" of Nephotettix cinticeps (UHLER, 1896) (Deltocephalinae: Chiasmini) [AB702994]. However, a nearly identical $16 \mathrm{~S}$ rDNA sequence of betaproteobacteria was detected in the betaproteobacterial symbiont of Deltocephalus sp. from the USA [AB772231].

The lengths of the analysed sequences were $820 \mathrm{pb}$ and $658 \mathrm{pb}$ for Sulcia and the proteobacterial symbionts, respectively. The base frequencies were approximately equal in the Sulcia symbionts $-30.6 \%$ A, $24.2 \%$ T, $18 \%$ C, $27.2 \%$ G - whereas in the proteobacterial symbionts they were $33.7 \%$ A, $26.6 \% \mathrm{~T}, 15.5 \% \mathrm{C}, 24.4 \% \mathrm{G}$.

Phylogenetic trees constructed using 16S rDNA sequences of Sulcia (Fig. 3) and betaproteobacterial symbionts (Fig. 4) of representatives of the Cicadellidae family confirmed the monophyly of symbionts of the Deltocephalinae subfamily with 0.98 and 0.99 posterior probability values, respectively.

Comparison of the results of ultrastructural observations and molecular identification has shown that electron-dense bacteria represent the Bacteroidetes symbiont Sulcia, and electron-translucent bacteria the betaproteobacterial symbiont Nasuia. 


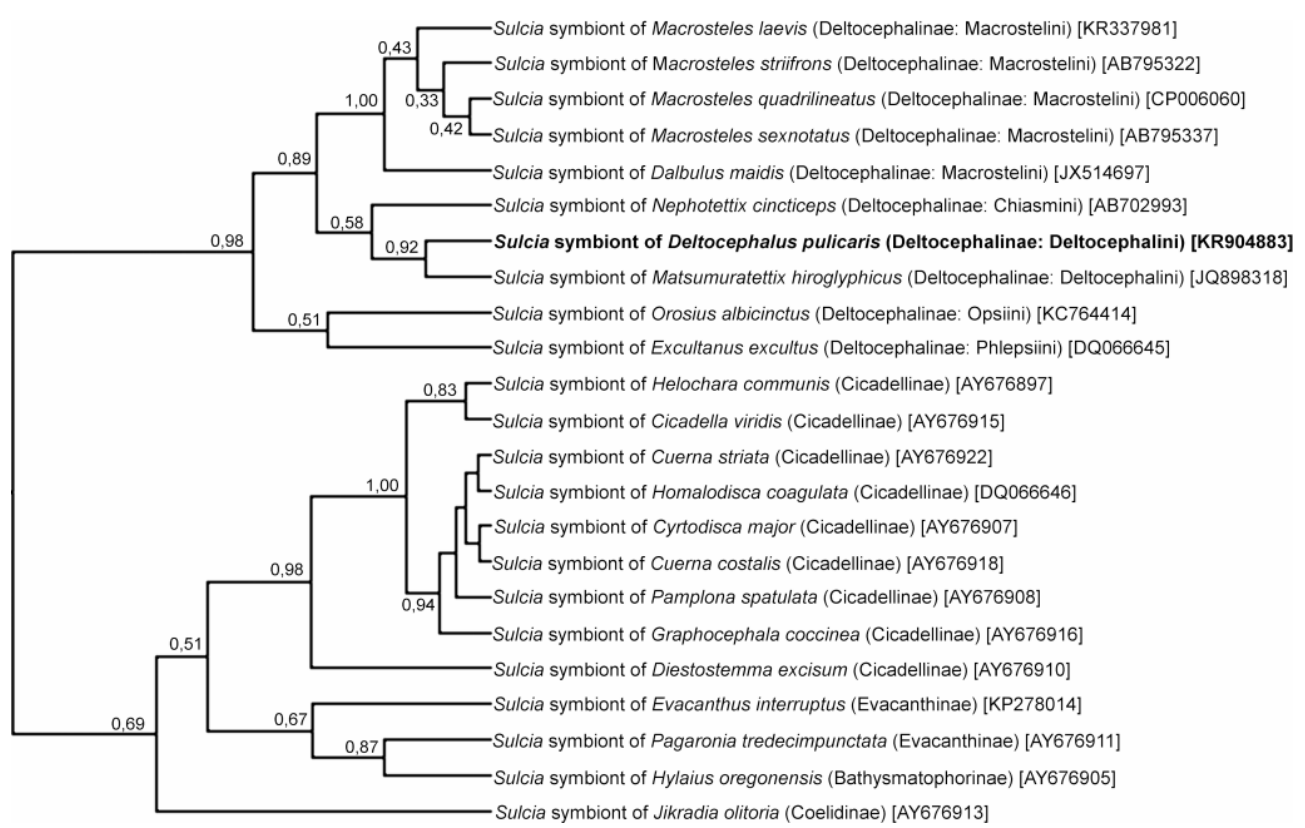

Fig. 3. Phylogenetic analysis of Sulcia symbionts of the representatives of Cicadomorpha on the basis of 16S rRNA gene sequences. The numbers indicate the posterior probabilities. Sequence accession numbers are shown in brackets.

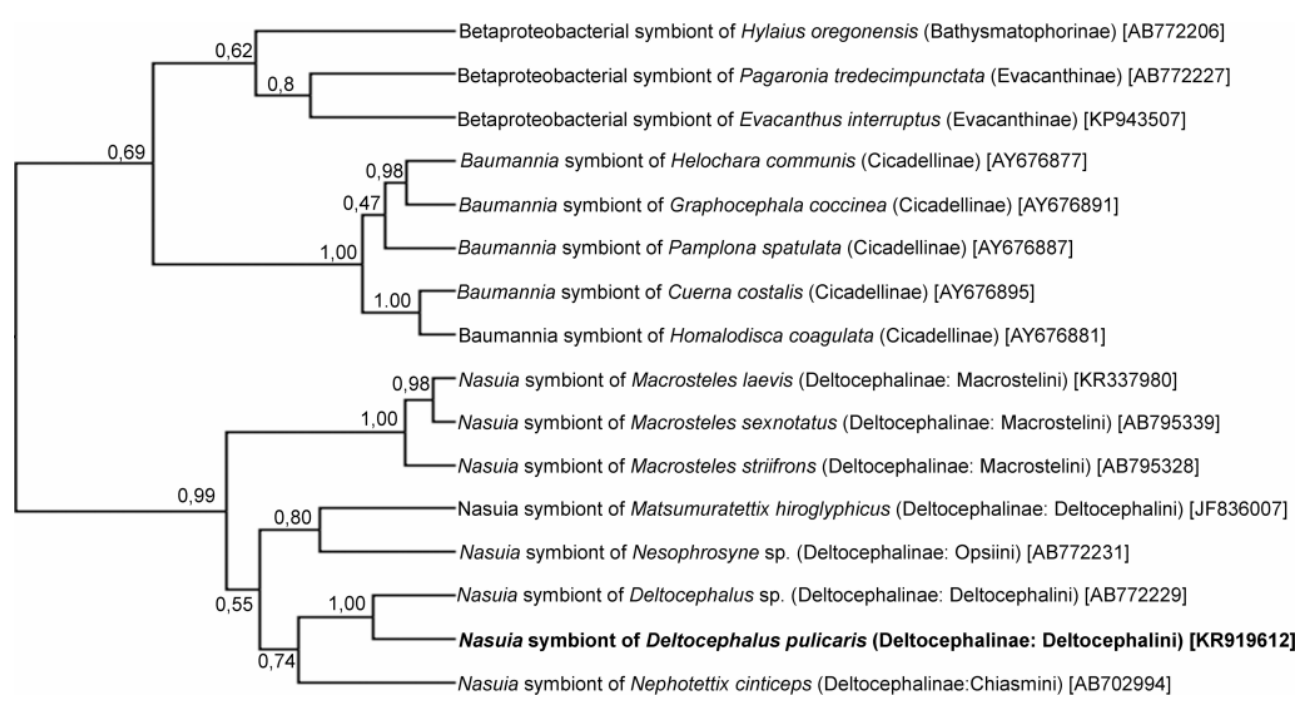

Fig. 4. Phylogenetic analysis of proteobacterial symbionts of the representatives of Cicadomorpha on the basis of $16 \mathrm{~S}$ rRNA gene sequences. The numbers indicate the posterior probabilities. Sequence accession numbers are shown in brackets. 


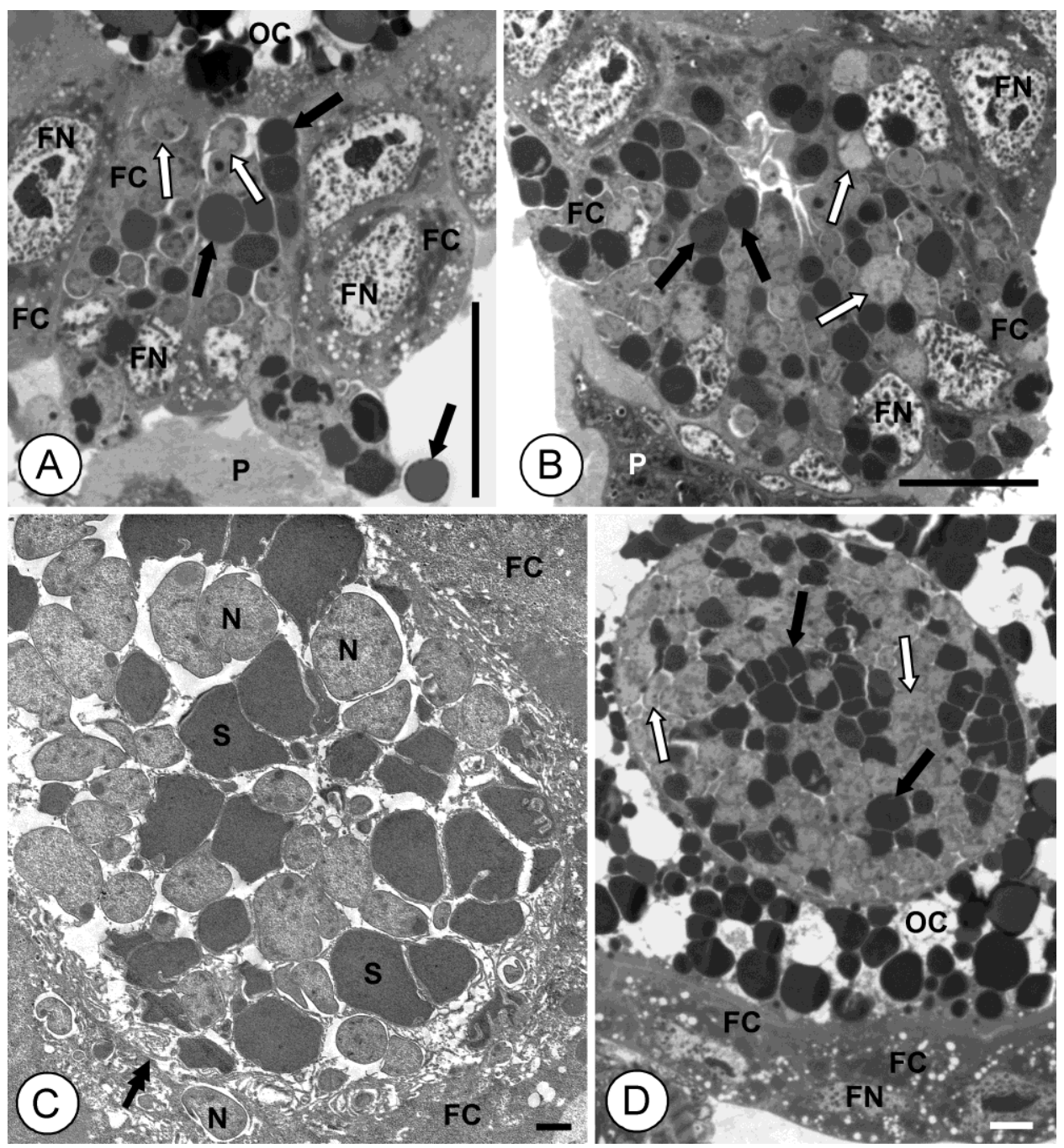

Fig. 5. Transovarial transmission of symbiotic microorganisms of $D$. pulicaris.

A. Bacteria Sulcia (black arrows) and Nasuia (white arrows) start to invade the follicular cells (FC) surrounding the posterior pole of the terminal oocyte (OC) (longitudinal section). FN - nucleus of follicular cell; P - ovariolar stalk (pedicel). Methylene blue, scale bar $=20 \mu \mathrm{m}$. B. Follicular cells (FC) surrounding the posterior pole of the oocyte filled with bacteria Sulcia (black arrows) and Nasuia (white arrows) (longitudinal section). FN - nucleus of follicular cell; P - ovariolar stalk (pedicel). Methylene blue, scale bar $=20 \mu \mathrm{m}$. C. Bacteria Sulcia $(\mathrm{S})$ and Nasuia $(\mathrm{N})$ start to gather in the perivitelline space (cross-section). FC - follicular cell; double arrow - oolemma. TEM, scale bar $=2 \mu \mathrm{m}$. D. Accumulation of bacteria Sulcia (black arrows) and Nasuia (white arrows) in the perivitelline space ("symbiont ball") (cross-section). FC - follicular cells; FN - nuclei of follicular cell; OC - oocyte. Methylene blue, scale bar $=20 \mu \mathrm{m}$. 


\section{Transovarial transmission of symbionts of $D$. pulicaris}

The symbiotic bacteria are transovarially (vertically) transmitted between generations. In mature females, both types of bacteria - Sulcia and Nasuia - leave the cytoplasm of the bacteriocytes and start to gather around the follicular epithelium surrounding the terminal oocytes that are at the stage of advanced vitellogenesis (Fig. 5A). During migration the bacteria change their pleomorphic shape to nearly spherical (Fig. 5A, B). The symbionts cross the membranes of the follicular cells and accumulate in their cytoplasm (Fig. 5A, B). This results in a marked increase in follicular cell volume (Fig. 5B). Then, the symbiotic bacteria leave them and accumulate in the space between the oocyte and follicular epithelium (termed perivitelline space). Finally, they assemble in the deep depression of the oolemma, forming "a symbiont ball" (Fig. 5C, D). The bacteria are isolated from the ooplasm by oolemma until the end of oogenesis (i.e. oocyte growth).

\section{DISCUSSION}

Results of earlier histological studies (MÜLLER 1962, BUCHNER 1965) and more recent ultrastructural and molecular analyses (MORAN et al. 2003, 2005, TAKIYA et al. 2006, MCCUTCHEON et al. 2009, MichALIK et al. 2014a, NODA et al. 2012, IsHII et al. 2013, Koga et al. 2013, BennetT \& Moran 2013, BennetT et al. 2014, Koga \& Moran 2014, SZKLARZEWICZ et al. 2015) have shown that representatives of Cicadomorpha are characterized by an enormous diversity of their symbionts. MORAN et al. (2005) and KOGA et al. (2013) suggested that the common ancestor of the Cicadomorpha and Fulgoromorpha acquired the bacterium Sulcia and the betaproteobacterial symbiont over 260 million years ago. During the subsequent evolution of these hemipterans, the betaproteobacterium was replaced by other types of bacteria, e.g. the gammaproteobacterium Baumannia in some Cicadellinae (TAKIYA et al. 2006), the alphaproteobacterium Hodgkinia in cicadas (MCCUTCHEON et al. 2009), and the gammaproteobacterium Sodalis in some spittlebugs (KogA et al. 2013). In the planthopper families Flatidae and Delphacidae, and in the leafhopper Scaphoideus titanus BALL, 1932 (Cicadellidae: Deltocephalinae), bacteria have been replaced by yeast symbionts (SACCHI et al. 2008, NODA et al. 1977, MiCHALIK et al. 2009). Recent analyses have shown that in some cicadomorphans (e.g. Aphrophora quadrinotata SAY, 1830, Macrosteles laevis (RIBAUT, 1927)) more than two obligate symbionts may occur (KoGA et al. 2013, KoBIAŁKA et al. 2015). According to KogA et al. (2013), the presence of three symbionts (i.e. Sulcia, the betaproteobacterium Zinderia and a Sodalis-like symbiont) in A. quadrinotata may represent a transitional state in which the most recently acquired Sodalis-like symbiont coexists with the ancestral betaproteobacterium, which has not yet been eliminated. This hypothesis corresponds well 
with the findings of MicHALIK et al. (2014a), which indicate that in the green leafhopper Cicadella viridis (LINNAEUS, 1758) the Sodalis-like symbiont co-resides with the bacterium Sulcia. Moreover, in C. viridis the Sodalis-like symbionts may occur in their own bacteriocytes or may co-reside in bacteriocytes with Sulcia. In the latter case, Sodalis-like symbionts infect cells of Sulcia resulting in the internalization of these microorganisms within the cells of Sulcia. Based on this observation, MicHALIK et al. (2014a) suggested that (1) symbiosis between $C$. viridis and the Sodalis-like symbiont represents an association "in statu nascendi", and (2) during the evolution of $C$. viridis, the bacterium Sodalis replaced the bacterium Baumannia. Thus, the above facts show that the kinds of possible symbiosis in cicadomorphans are much more complex than those present in other hemipterans.

Previous studies of symbiotic systems in Deltocephalinae leafhoppers have shown that members of this subfamily are characterized by diverse types of symbionts (BUCHNER 1925, 1965, MÜLler 1962, MARZORATI et al. 2006, SACCHI et al. 2008, WANGKEEREE et al. 2011, NODA et al. 2012, BENNETT et al. 2013, ISHII et al. 2013, KobiaŁKA et al. 2015). As a rule, the Deltocephalinae leafhoppers harbour the bacterium Sulcia and the betaproteobacterium Nasuia (WANGKEEREE et al. 2011, NODA et al. 2012, BENNETT \& Moran 2013, IsHII et al. 2013, KobiatKA et al. 2015, this study) which MÜLLER (1962) termed $a$-symbionts and $t$-symbionts, respectively. However, yeast symbionts are present in Scaphoideus titanus (tribe Scaphoideini) (MARZORATI et al. 2006, SACCHI et al. 2008) and Graphocraerus ventralis (FALLÉN, 1806) (tribe Athysanini) (KOBIALKA, in preparation). In $S$. titanus the yeast symbionts are accompanied by the Bacteroidetes symbiont Cardinium (BIGLIARDI et al. 2006, SACCHI et al. 2008), but in G. ventralis by the Bacteroidetes symbiont Sulcia (KoBIAŁKA, in preparation). It has also been observed that besides Sulcia and the betaproteobacterium Nasuia another symbiont - the gammaproteobacterium Arsenophonus - is present in Macrosteles laevis. Moreover, the bacterium Arsenophonus does not occur separately but is internalized within the cells of Sulcia (KOBIAŁKA et al. 2015).

Molecular and ultrastructural studies have shown that the leafhopper $D$. pulicaris harbours Sulcia and Nasuia bacteria. Molecular phylogenetic analyses have shown that both symbionts of D. pulicaris form well-defined monophyletic groups with Sulcia and the betaproteobacterial symbionts of other Deltocephalinae leafhoppers (Figs 3 and 4). The results of these analyses correspond well with the recent classification of Deltocephalinae leafhoppers proposed by ZAHNISER \& DIETRICH (2013).

Earlier histological analyses (MÜLLER 1962, BUCHNER 1965), as well as more recent ultrastructural ones, have shown that hemipterans developed various means of transmitting symbionts from one generation to the next (CHENG \& HOU 2001, SzKLARZEWICZ \& Moskal 2001, SZKLARZEWICZ et al. 2006, 2010, 2013, 2015, SACCHI et al. 2008, 
MichaLIK et al. 2009, 2013, 2014a, 2014b, KUECHLER et al. 2010, 2011, MATSUURA et al. 2012, SwiatoniowsKa et al. 2013). Symbionts may infect larval ovaries containing undifferentiated germ cells or ovaries of adult females containing vitellogenic or choriogenic oocytes. In the latter case, the ovary may be invaded by individual symbionts (i.e. released from the bacteriocytes) or by whole, intact bacteriocytes. The symbionts may enter the cytoplasm of follicular cells or may migrate between neighbouring follicular cells. The microorganisms may invade the posterior or anterior pole of the oocyte. The symbionts may enter the oocyte cytoplasm or may assemble in the deep invagination of the oolemma and remain outside the oocyte until the end of its growth. An unusual situation has been found in two genera of the heteropteran family Lygaeidae, Nysius ericae (SCHILLING, 1829) and Nithecus jacobaeae (SCHILLING, 1829) (MATSUURA et al. 2012, SWIATONIOWSKA et al. 2013), in which the ovarioles contain not only germ cells (oocytes and trophocytes) and follicular cells but also bacteriocytes. The latter are situated in the basal region of the tropharium - this is known as the "infection zone". The previtellogenic oocytes located within the "infection zone" are infected by bacteria released from the bacteriocytes surrounding them. It should be stressed that different modes of symbiont transmission may occur even within the same group of hemipterans. Results of research into the symbiotic systems of members of Cicadomorpha (BUCHNER 1965, SACCHI et al. 2008, MiCHALIK et al. 2014a, KoBiAŁKA et al. 2015, SZKLARZEWICZ et al. 2015) indicate that their symbionts always invade follicular cells surrounding terminal oocytes during vitellogenesis. The microorganisms do not enter the oocyte but remain in the perivitelline space in the form of a sphere or lens. Thus, it seems that cicadomorphans, in contrast to other hemipterans, are characterized by a similar mode of transovarial transmission of symbiotic microorganisms from the mother to the offspring.

\section{ACKNOWLEDGEMENTS}

We are greatly indebted to Ada JANKOWSKA and Olga WoźNICKA for their skilful technical assistance.

This work was supported by funds from research grant K/DSC/002334.

\section{REFERENCES}

BAumann P. 2005. Biology of bacteriocyte-associated endosymbionts of plant sap-sucking insects. Annual Review of Microbiology 59: 155-189. 
BAUMANn P. 2006. Diversity of prokaryote-insect associations within the Sternorrhyncha (psyllids, whiteflies, aphids, mealybugs). [in]: T.A. MiLler, K. BouRTzIs (eds.). Insect Symbiosis, Vol. 2. Contemporary Topics in Entomology Series, CRC, Boca Raton, 1-24.

BenNETT G.M., Moran N.A. 2013. Small, smaller, smallest: the origin and evolution of ancient dual symbioses in a phloem-feeding insect. Genome Biology and Evolution 5(9): 1675-1688.

Bennett G.M., McCutcheon J.P., McDonald B.R., Romanovicz D., Moran N.A. 2014. Differential genome evolution between companion symbionts in an insect-bacterial symbiosis. mBio 5(5): e01697-14.

Bigliardi E., Sacchi L., Genchi M., Alma A., Pajoro M., Daffonchio D., Marzorati M., AvanZATI A.M. 2006. Ultrastructure of a novel Cardinium sp. symbiont in Scaphoideus titanus (Hemiptera: Cicadellidae). Tissue and Cell 38(4): 257-261.

BILIŃSKI S. 1998. Introductory remarks. Folia Histochemica et Cytobiologica 36(4): 143-145.

BuCHNER P. 1925. Studien an intracellularen Symbionten. V. Die symbiotischen Einrichtungen der Zikaden. Zeitschrift für Morphologie und Ökologie der Tiere 4(1): 88-245.

BUCHNER P. 1965. Endosymbiosis of animals with plant microorganisms. Interscience Publishers, New York - London - Sydney.

BÜNING J. 1994. The ovary of Ectognatha, the insects s.str. [in]: J. BüNING (ed.). The Insect Ovary: Ultrastructure, Previtellogenic Growth and Evolution. Chapman and Hall, London, 31-305.

CHENG D.J., Hou R.F. 2001. Histological observations on transovarial transmission of a yeast-like symbiote in Nilaparvata lugens STÅL (Homoptera, Delphacidae). Tissue and Cell 33(3): 273-279.

Douglas A.E. 1998. Nutritional Interactions in Insect-Microbial Symbioses: Aphids and Their Symbiotic Bacteria Buchnera. Annual Review of Entomology 43(1): 17-37.

Douglas A.E. 2003. The nutritional physiology of aphids. Advances in Insect Physiology 31: 73-140.

Douglas A.E. 2006. Phloem sap feeding by animals: problems and solutions. Journal of Experimental Botany 57(4): 747-754

HALL T.A. 1999. BIOEDIT: an user-friendly biological sequence alignment editor and analysis program for Windows 95/98/NT. Nucleic Acids Symposium Series 41: 95-98.

Ishil Y., MatsunRa Y., Kakizawa S., NikOH N., Fukatsu T. 2013. Diversity of bacterial endosymbionts associated with Macrosteles leafhoppers vectoring phytopathogenic phytoplasmas. Applied and Environmental Microbiology 79(16): 5013-5022.

KIKUCHI Y. 2009. Endosymbiotic bacteria in insects: their diversity and culturability. Microbes and Environments 24(3): 195-204.

Kobialka M., Michalik A., Walczak M., Junkiert Ł., SzKlarzewicz T. 2015. Sulcia symbiont of the leafhopper Macrosteles laevis (Ribaut, 1927) (Insecta, Hemiptera, Cicadellidae: Deltocephalinae) harbors Arsenophonus bacteria. Protoplasma (early view), doi: 10.1007/s00709015-0854-x.

Koga R., Moran N.A. 2014. Swapping symbionts in spittlebugs: evolutionary replacement of a reduced genome symbiont. International Society for Microbial Ecology Journal 8(6): $1237-1246$ 
Koga R., Bennett G.M., Cryan J.R., Moran N.A. 2013. Evolutionary replacement of symbionts in an ancient and diverse insect lineage. Environmental Microbiology 15(7): 2073-2081.

KueChler S.M., DetTNER K., KeHL S. 2010. Molecular characterization and localization of the obligate endosymbiotic bacterium in the birch catkin bug Kleidocerys resedae (Heteroptera: Lygaeidae, Ischnorhynchinae). Microbiology Ecology 73(2): 408-418.

KueChler S.M. , DetTNER K., KeHL S. 2011. Characterization of an obligate intracellular bacterium in the midgut epithelium of the bulrush bug Chilacis typhae (Heteroptera, Lygaeidae, Artheneinae). Applied and Environmental Microbiology 77(9): 2869-2876.

Marzorati M., Alma A., Sacchi L., Pajoro M., Palermo S., Brusetti L., Raddadi N., Balloi A., Tedeschi R., Clementi E., Corona S., Quaglino F., Bianco P.A., Beninati T., Bandi C., DAFFONCHIO D. 2006. A novel Bacteroidetes symbiont is localized in Scaphoideus titanus, the insect vector of flavescence dorée in Vitis vinifera. Applied and Environmental Microbiology 72(2): 1467-1475.

Matsuura Y., Kikuchi Y., Hosokawa T., Koga R., Meng X.Y., Kamagata Y., Nikoh N., Fukatsu T. 2012. Evolution of symbiotic organs and endosymbionts in lygaeid stinkbugs. International Society for Microbial Ecology Journal 6(2): 397-409.

McCuTCheOn J.P., MoRAn N.A. 2007. Parallel genomic evolution and metabolic interdependence in an ancient symbiosis. Proceedings of the National Academy of Sciences 104(49): 19392-19397.

McCutcheOn J.P., MoRAn N.A. 2010. Functional convergence in reduced genomes of bacterial symbionts spanning 200 My of evolution. Genome Biology and Evolution 2: 708-718.

McCuTCheOn J.P., McDonald B.R., Moran N.A. 2009. Convergent evolution of metabolic roles in bacterial co-symbionts of insects. Proceedings of the National Academy of Sciences 106(36): 15394-15399.

MichaliK A., JANKOWSKA W., SZKLARZEWICZ T. 2009. Ultrastructure and transovarial transmission of endosymbiotic microorgansms in Conomelus anceps and Metcalfa pruinosa (Insecta, Hemiptera, Fulgoromorpha). Folia Biologica 57(3-4): 131-137.

Michalik A., Golas A., Kot M., Wieczorek K., Szklarzewicz T. 2013. Endosymbiotic microorganisms in Adelges (Sacchiphantes) viridis (Insecta, Hemiptera, Adelgoidea: Adelgidae): Molecular characterization, ultrastructure and transovarial transmission. Arthropod Structure and Development 42(6): 531-538.

Michalik A., Jankowska W., Kot M., GoŁas A., Szklarzewicz T. 2014a. Symbiosis in the green leafhopper, Cicadella viridis (Hemiptera, Cicadellidae). Association in statu nascendi? Arthropod Structure and Development 43(6): 579-587.

MichaliK A., SzKLARZewicz T., JANKowsKa W., WieczoreK K. 2014b. Endosymbiotic microorganisms of aphids (Hemiptera: Sternorrhyncha: Aphidoidea): Ultrastructure, distribution and transovarial transmission. European Journal of Entomology 111(1): 91-104.

Montlor C.B., MaXmen A., PurCell A.H. 2002. Facultative bacterial endosymbionts benefit pea aphids Acyrthosiphon pisum under heat stress. Ecological Entomology 27(2): 189-195.

MoRAn N.A., DALE C. 2006. Molecular interactions between bacterial symbionts and their hosts cells. Cell 126(3): 453-465. 
Moran N.A., Dale C., Dunbar H., Smith W.A., Ochman H. 2003. Intracellular symbionts of sharpshooters (Insecta: Hemiptera: Cicadellinae) form a distinct clade with a small genome. Environmental Microbiology 5(2): 116-126.

Moran N.A., Tran P., Gerardo N.M. 2005. Symbiosis and insect diversification: an ancient symbiont of sap-feeding insects from the bacterial phylum Bacteroidetes. Applied and Environmental Microbiology 71(12): 8802-8810.

MÜLLER H.J. 1962. Neuere Vorstellungen über Verbreitung und Phylogenie der Endosymbiosen der Zikaden. Zeitschrift für Morphologie und Ökologie der Tiere 51(2): 190-210.

NODA H. 1977. Histological and histochemical observation of intracellular yeast-like symbiotes in the fat body of the small brown planthopper, Laodelphax striatellus (Homoptera: Delphacidae). Applied and Entomological Zoology 12(2): 134-141.

Noda H., Watanabe K., Kawai S., Yukuhiro F., Miyoshi T., Tomizawa M., Koizumi Y., Nikoh N., FUKATSU T. 2012. Bacteriome-associated endosymbionts of the green rice leafhopper Nephotettix cincticeps (Hemiptera: Cicadellidae). Applied and Entomological Zoology 47(3): 217-225.

Oliver K.M., Russell J.A., Moran N.A., Hunter M.S. 2003. Facultative bacterial symbionts in aphids confer resistance to parasitic wasps. Proceedings of the National Academy of Sciences 100(4): 1803-1807.

RAmbAut A., DRUMmond A.J. 2007. BEAST: Bayesian evolutionary analysis by sampling trees. BMC Evolutionary Biology 7: 214.

Sacchi L., Genchi M., Clementi E., Bigliardi E., Avanzatti A.M., Pajoroi M., Negri I., Marzorati M., Gonella E., Alma A., DafFonchio D., Bandi C. 2008. Multiple symbiosis in the leafhopper Scaphoideus titanus (Hemiptera: Cicadellidae): Details of transovarial transmission of Cardinium sp. and yeast-like endosymbionts. Tissue and Cell 40(4): 231-242.

Scarborough C.L., Ferrari J., Godfray H.C.J. 2005. Aphid protected from pathogen by endosymbiont. Science 310(5755): 1781.

Swiatoniowska M., Ogorzalek A., Golas A., Michalik A. , Szklarzewicz T. 2013. Ultrastructure, distribution, and transovarial transmission of symbiotic microorganisms in Nysius ericae and Nithecus jacobaeae (Heteroptera: Lygaeidae: Orsillinae). Protoplasma 250(1): $325-332$.

SzKLARZEWiCZ T., Moskal A. 2001. Ultrastructure, distribution and transmission of endosymbionts in the whitefly Aleurochiton aceris Modeer (Insecta, Hemiptera, Aleyrodinea). Protoplasma 218(1-2): 45-53.

SzKLARZEWICZ T., KęDRA K., NiżNIK S. 2006. Ultrastructure and transovarial transmission of endosymbiotic microorganisms in Palaeococcus fuscipennis (Burmeister) (Insecta, Hemiptera, Coccinea: Monophlebidae). Folia Biologica 54(1-2): 69-74.

SzklarZewicz T. , Michalik A., CZaja A., SzydŁowska S. 2010. Germ cell cluster formation and ovariole structure in Puto albicans and Crypticerya morrilli (Hemiptera: Coccinea). Phylogenetic implications. European Journal of Entomology 107(4): 589-595.

Szklarzewicz T., Kalandyk-KolodZiejczyK M., Kot M., Michalik A. 2013. Ovary structure and transovarial transmission of endosymbiotic microorganisms in Marchalina hellenica (Insecta, Hemiptera, Coccomorpha: Marchalinidae). Acta Zoologica 94(2): 184-192. 
Szklarzewicz T., Grzywacz B., Szwedo J., Michalik A. 2015. Bacterial symbionts of the leafhopper Evacanthus interruptus (Linnaeus, 1758) (Insecta, Hemiptera, Cicadellidae: Evacanthinae). Protoplasma (early view), doi:10.1007/s00709-015-0817-2.

TakiYa D.M., Tran P., Dietrich C.H., Moran N.A. 2006. Co-cladogenesis spanning three phyla: leafhoppers (Insecta: Hemiptera: Cicadellidae) and their dual bacterial symbionts. Molecular Ecology 15(13): 4175-4191.

Thompson J.D., Gibson T.J., Plewniak F., Jeanmougin F., Higgins D.G. 1997. The ClustalX windows interface: Flexible strategies for multiple sequence alignment aided by quality analysis tools. Nucleic Acids Research 25(24): 4876-4882.

Urban J., Cryan J. 2012. Two ancient bacterial endosymbionts have coevolved with the planthoppers (Insecta: Hemiptera: Fulgoroidea). BMC Evolutionary Biology 12: 87.

Wangkeeree J., Miller T.A., Hanboonsong Y. 2011. Predominant bacteria symbionts in the leafhopper Matsumuratettix hiroglyphicus - the vector of sugarcane white leaf phytoplasma. Bulletin of Insectology 64(Suppl.): 215-216.

Wu D., Daugherty S.C., Van Aken S.E., Pai G.H., Watkins K.L., Khouri H. 2006. Metabolic complementarity and genomics of the dual symbiosis of sharpshooters. PLoS Biology 4: e188.

ZAHNiSER J.N., Dietrich C.H. 2013. A review of the tribes of Deltocephalinae (Hemiptera: Auchenorrhyncha: Cicadellidae). European Journal of Taxonomy 45: 1-211.

Received: 4 July 2015

Accepted: 13 August 2015 